\title{
格子渦法における粘性拡散に関する研究*
}

\author{
蔦 原 道 久*1, 木 村 雄 吉*2 \\ 小川和 彦*2, 細川泰 宏*3
}

\section{A Study of Viscous Diffusion in Lattice Vortex Method}

\author{
Michihisa TSUTAHARA, Takeyoshi KIMURA, \\ Kazuhiko OGAWA and Yasuhiro HOSOKAWA
}

\begin{abstract}
The Lattice vortex method (LVM) by introducing virtual vortices has been proposed by the authors. This paper has focused on the treatment of viscous diffusion of vortices. From the result of calculation of a convection diffusion equation, giving a vorticity distribution of one vortex by the Gauss distribution offered good accuracy in the calculation of vortex diffusion and this method made the limitation of the Courant number relaxed. In the flow analysis by the LVM, the convection of vortices was calculated by secondorder area weighting scheme. It was found that the combination of this scheme and vorticity distribution determined by Gaussian distribution offered good result. Moreover, the result of cavity flow analysis turned out to be having sufficient accuracy by comparing with the result of the finite difference method. Therefore, LVM can be used for inner flow that the conventional vortex method is not so used.
\end{abstract}

Key Words: Computational Fluid Dynamics, Vortex, Viscous Flow, Vortex Diffusion, Vortex Method, Cavity Flow

\section{1. 緒言}

いわゆる離散渦法は, 高レイノルズ数の流れに適用 され，その簡便さから広く用いられてきた。しかし外 部流れにおいては，時間発展とともに渦の数が膨大な ものとなり,ビオ・サバール則からの誘導速度の計算 に対する計算機の負荷が極めて大きくなるという問題 があった、これを解決する手段として，領域に格子を とり，各格子点での渦度から二次元であれば，流れの 関数をポアソン方程式から求め,これから各瀜の移動 速度を計算して時間発展を進めるVIC 法(1)(2) がある。 また近年は離散渦法の適用の範囲が中間レイノルズ数 あるいは低レイノルズ数の流れと広がってきている。 しかしここで問題になるのは，渦の拡散をいかに計算 に取り入れるかである。基本的には渦にコアをもたせ る方法, また離散渦を渦度拡散に見合うように移動さ せる方法が必要である。

著者らは前報 ${ }^{(3)(4)}$ において，格子として正方形格子 を用い毎時間ステップに渦を格子点に再配置する手法

* 原稿受付 1997 年 4 月 30 日

*1 让員, 神 $)$ - 大学自然科学研究科( $657-8501$ 神户市灘区谷 甲台町 1-1).

*2 正員, 神于大学上学部.

*3 神厂大学大学院.
を提案し(ここでは格子渦法と呼んでおく), 従来離散 渦法が苦手としていた内部流れにも適用し，正方形キ ヤビティ流れにおいても十分な精度で計算が可能なこ とを示した。しかし，前報では渦の移流の問題に話を 限っており，粘性拡散については中心差分によって計 算を行っていた。 また，提案した手法と一般の差分法 との相違についても言及はしたが，まだ検討すべき点 が多いように思われる。

そこで，本論文では粘性拡散として，前述の手法の うち後者のみ，すなわち渦を適当な方法で移動させる ことによる手法のいくつかをこの格子洞法に適用して 問題点を明らかにし，より適切な手法を提案する。ま た粘性拡散をも含めた議論で,この手法をあくまでラ グランジェ的に渦を移動させていることを述べ, 差分 法との相違を明らかにするとともに，いわゆる移動拡 散問題での陽的な解法において遭遇する，いわりる CFL 条件，あるいは拡散数による制限について，今回 の万法がこれらの制限を緩和する可能性があることに ついても考祭する。

\section{2. 一次元拡散方程式についての考察}

\section{一次元拡散方程式は}




$$
\frac{\partial \omega}{\partial t}=\nu \frac{\partial^{2} \omega}{\partial x^{2}}
$$

と表される。ここでは, 従来の離散渦法で用いられて いる㹡散速度による方法およびランダムウォーク法に ついて，格子渦法に用いた場合の問題点を検討し，新 しい手法の基礎となる考え方について説明する。計算 精度の比較については式(1)を FTCS (時間前進差分, 空間中心差分)で離散化し陽解法で解いたもので, 拡 散数 $D=v \Delta t / \Delta x^{2}$ は 0.01 としており厳密解との差は ほとんどないとみなせる結果を基準としている。

$2 \cdot 1$ 粘性拡散速度による検討 大上・赤松(5),

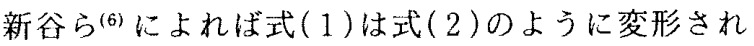
る.

$$
\frac{\partial \omega}{\partial t}+\frac{\partial}{\partial x}\left\{\left(u+u_{d}\right) \omega\right\}=0
$$

ただし

$$
u_{d}=-\frac{\nu}{\omega} \frac{\partial \omega}{\partial x}
$$

$u_{d}$ はちょうど速度の次元をもっており, これは粘性 拡散速度あるいは渦拡散速度とよばれ，二次元の場合 移流による速度にこの速度を加えたもので渦点を移動 させることにより，粘性による拡散を計算に取り入れ 得るとしている。

この項はたしかに瀜の昖散による循環の移動量であ るが, 式 (2)第 1 項のオイラー的な単位体積あたりの

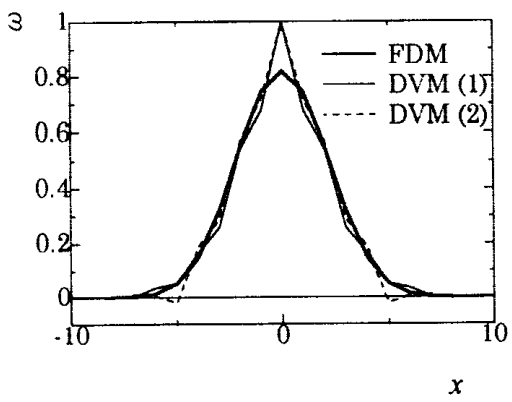

(a) $t=10$

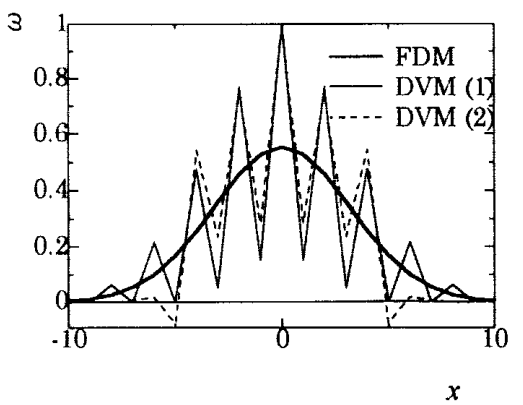

(b) $t=40$

Fig. 1 Diffusion Velocity Method (Vorticity distributes on one cell at the beginning of the analysis)
渦度の変化に対応するのはここの項を空間的にもう一 度微分した 2 階微分である. 特に問題になるのは式 （2）を離散化したときで，例えば中心差分を用いた場 合，後述するような空間的に滑らかな極大值をもつよ うな場合，2階微分は有限であるのに，1階微分は零と なってこの部分は渦の拡散がないことになる。片側差 分を用いると前後非対称な拡散となるばかりか, 本来 の拡散の物理的なメカ二ズムが失われることになる。

図 1 および図 2 に式 (2)の粘性拡散速度の式を用い て解析した結果を次に示す。粘性拡散速度による渦度 の移流については，著者らが前報で述べた面積配分法 によって計算しており，図 1,2 中において DVM(1) は一次精度の面積配分法, DVM (2) は二次精度の面 積配分による結果を示す。図 1 は最初に渦度が一つの セルにあるものとし，それが拡散した場合の結果であ るが，上述のように最初に瀜度を分布きせた $x=0$ の セルでは1階微分が零となるため, DVM(1)および DVM (2)0いずれも $x=0$ の洞度がまったく拡散し ていないことがわかる。また図 2 は二つのセルにまた がって渦度を分布させてその拡散を解析した結果であ り，図10場合と比べて若干は改善されるが，図 2(b)0ようにある時間が経過すると二次精度の解が 振動していることがわかる。このように粘性拡散速度 による解析方法は，離散渦法では計算負荷の少ない簡

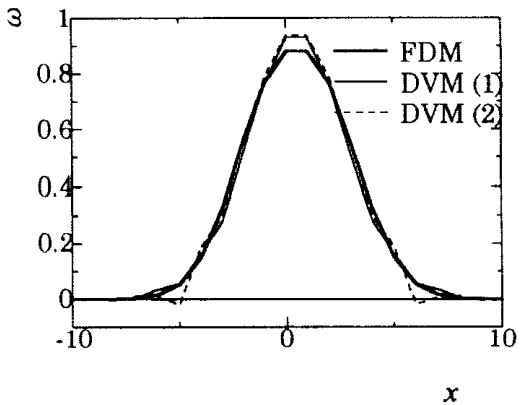

(a) $t=10$

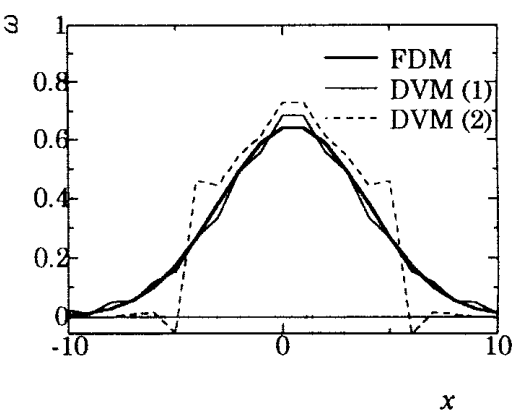

(b) $t=40$

Fig. 2 Diffusion Velocity Method (Vorticity distributes on two lattice at two cells at the beginning of the analysis) 
便な方法であるが，やはりこう配のとり方や初期条件 によって解析が困難となる場合のあることがわかっ た.

$2 \cdot 2$ ランダムウォーク法による検討 ランダム ウォークは連続体近似により移流拡散を表すフォッカ 一・プランク方程式となることがわかっており，拡散 方程式のシミュレーションとして有効なものである. 難点はノイズの大きいことであるが，また今回のよう に渦を格子に時間ステップごとに再配置する場合の数 值拡散についても不明であるのでこれらについて検討 した.

図 3 に抎散数 $D=0.01$, 時刻 $t=10$ の場合の結果を 示す。渦の移動は $2 \cdot 1$ 節と同じ面積配分法によるもの で, 図 3 中の RWM(1) は一次精度の面積配分法, RWM (2) は二次精度の面積配分法による結果を示 す。図3(a) は渦を分割しない場合，(b)，（c）はそ れぞれ渦を 10 個および 100 個に分割した場合の結果

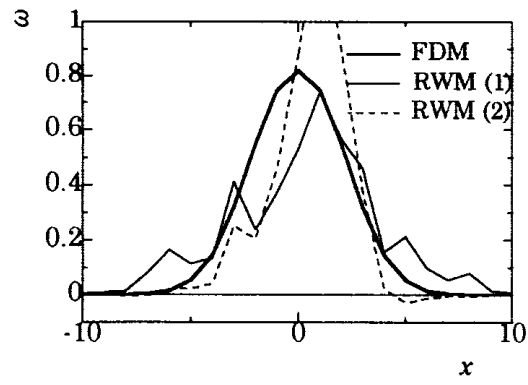

(a) $t=10, N=1$

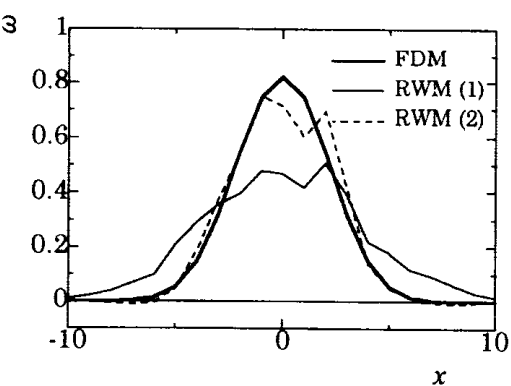

(b) $t=10, N=10$

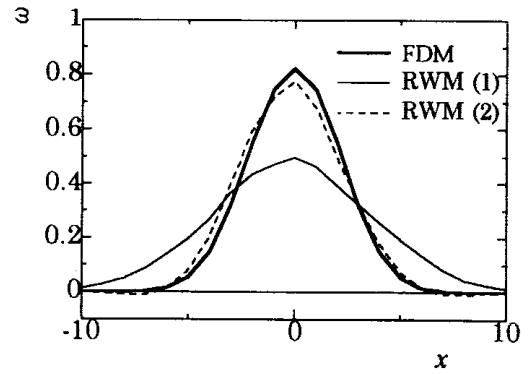

(c) $t=10, \quad N=100$

Fig. 3 Random Walk Method ( $t$ : time, $N$ : Number of vorticity elements)
を示す。なお FDM は差分法による結果である，渦の 分割を增加させると精度が向上することは明らかであ り，また渦の再配置については一次精度の面積配分法 では渦の分割数を増加させても数値拡散が大きいため 解の精度は向上しないが，二次精度の面積配分法では 差分法と同等の解が得られることがわかる。

$2 \cdot 3$ 提案する渦拡散手法 $2 \cdot 2$ 節で示したよう に, ランダムウォークは粒子(ここでは渦点)の数を増 やすことにより精度が増すことがわかる，大数の法則 によるランダムウォークによる粒子の分布は, 粒子の 数が増加した極限で正規分布となることがわかってい るから，今回のように格子に渦を再配置する場合，拡 散のシミュレーションとしては最初から正規分布とな るように，渦を配分すればよい。この配分は式 $(3)$ を 初期条件とする抎散方程式 (1) 0)基本解式 (4)

$$
\begin{aligned}
& \omega(x)=\left\{\begin{array}{ll}
1 & (-\Delta x / 2 \leq x \leq \Delta x / 2) \\
0 & (x<-\Delta x / 2, \Delta x / 2<x)
\end{array} \cdots \cdots \cdots(3)\right. \\
& \omega(x)=\frac{1}{2}\left\{\operatorname{erf}\left(\frac{\Delta x / 2-x}{2 \sqrt{v t}}\right)+\operatorname{erf}\left(\frac{\Delta x / 2+x}{2 \sqrt{v t}}\right)\right\}
\end{aligned}
$$

からあらかじめ求めることができる。しかし，すぐに わかるように理論的には渦度は流れ場全体に広がり， ほとんどの領域では無視できるほど小さな値であるに もかかわらず，これらをすべての格子点に配分するの は極めて計算の効率が悪い。一方，中心差分を考虑す ると，渦度は両隣の格子点に配分されるのみであるが， $D$ を小さく選べば十分な精度で計算することができ る.

そこで本手法ではこの渦度の拡散する領域を有限の 範四に限ることにし，以下の考察に基づいて渦㹡散手 法を提案する。いま，昖散方程式を FTCSで離散化 した場合の，演算のプロセスを考えると，

$\omega_{i}^{n+1}=\omega_{i}^{n}+D\left(\omega_{i-1}^{n}-2 \omega_{i}^{n}+\omega_{i+1}^{n}\right)$

となる。ここで $D\left(=v \Delta t / \Delta x^{2}\right)$ は拡散数である，時間 ステップが一つ進むと，この格子点では渦度が $2 D \omega_{i}^{n}$ だけ減少し，近接した 2 格子にそれぞれD号だけ配 分されることになる。

FTCS におけるノイマンの収束判定では $D<1 / 2$ で 計算は安定であるということであるが，1格子でのみ 渦度が集中しているような初期值問題を考えると $D$ $>1 / 3$ において振動する解となり，これでは中心差分 が成り立つために必要な条件である解の滑らかさが保 てない，また $D=1 / 2$ の場合，初期に渦度が集中して いた格子では，渦度が零となることは明らかである。 実際にはある点での渦度は時間が無限大になるまで零 になることはないはずである。すなわち FTCSでは、 
$D$ が大きいとき，安定条件を満たしていても，この格 子での渦度の隇少が大きすぎることがわかる。これ は，差分の精度を上げても基本的に同じである。この ように 1 時間ステップ後の差分では拡散数 $D$ の制約 が強いため，そこで次のように 2 時間ステップ後の差 分を検討した。

式（5)の場合，前述のように注目した渦度 $\omega_{i}^{n} か ゙$ 搪

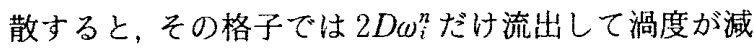
少し，隣接の左右の格子では渦度がそれぞれD $D \omega_{i}^{n} た ~$ け増加する，次の時間ステップすなわち2 時間ステッ プ後では，注目した格子には隣接の 2 格子からそれぞ れ $D \times D \omega_{i}^{n}$ だけ流入してくる(渦度が戻ってくる)の で, 注目した格子の渦度は $(1-2 D+2 D \times D) \omega_{i}^{n}$ とな る。また注目した格子の両隣の格子は同様に考えると $(D-2 D \times D) \omega_{i}^{n}$ の渦度，さらにその隣の格子は $(D \times$ $D-2 D \times D \times D) \omega_{i}^{n}$ の渦度となる。このような考え方 で 2 時間ステップ後の渦度分布を与えると解はいくぶ ん滑らかになる。このような瀜度尔布を1時間ステッ プで与えることにすると，势散による渦度分布が同じ $D に$ 対してより正規分布に近い形となるのは，明らか である，以上のような渦拡散手法の精度について，3 章で検証していく.

\section{3. 一次元移流拡散方程式への適用}

格子渦法を線形の一次元バーガース方程式 (6)に適 用した結果は前報においても報告したが, 前報では拡 散は中心差分により行っていた。本論文では，2 章に おいて提案した渦払散の手法と, 前報で提案した移流 に対する二次精度の手法を用いて計算を行った。

$$
\frac{\partial \omega}{\partial t}+u \frac{\partial \omega}{\partial x}=\nu \frac{\partial^{2} \omega}{\partial x^{2}}
$$

$3 \cdot 1$ 計算の手順本計算法では, 移流と拡散と を交互に行うので，一般の演算子の分割手順 ${ }^{(7)(8)} に よ$ 门,

$$
L D(\Delta t / 2) L C(\Delta t) L D(\Delta t / 2)
$$

として時間ステップ $\Delta t$ を進めることとする。ここで, $L D$ は拡散の計算, $L C$ は移流の計算を示す。すなわ ち1ステップ進めるのに始めと終わりに抎散の計算を 1/2 ステップ行うのである.

また前報でも述べたように，本手法での計算には， 格子点はラグランジェ的に移動させる渦の時間ステッ プごとの再配置に用いられるのであって，差分法ある いは有限体積法のように，オイラー的な変数を離散化 するために用いられるものと異なっている，したがっ て渦は 1 セル以上超えて移動することも可能であり， いおゆる CFL 条件も本質的には存在しない。

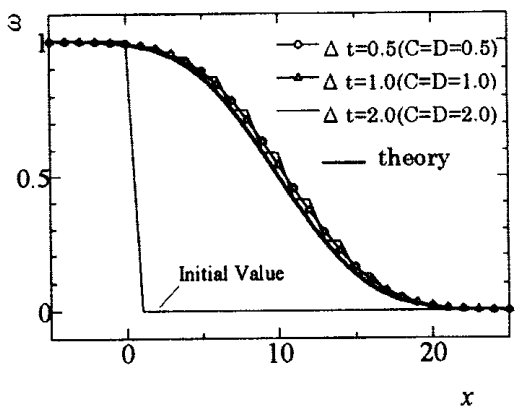

(a) Initial condition $[\omega(x)=1(x<0), \omega(x)=0(0 \leq x)], t=10$

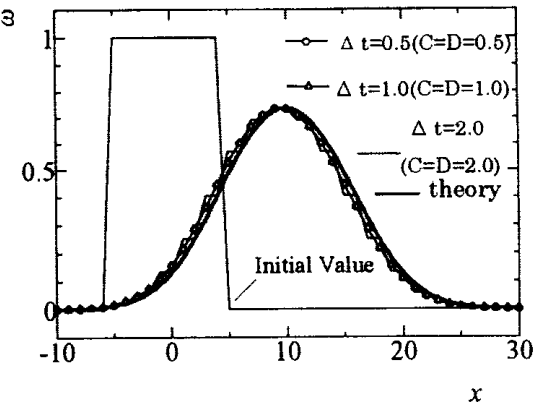

(b) Initial condition $[\omega(x)=1(-5 \leq x \leq 5), \omega(x)=0,(x<-5$, $5<x)], t=10$

Fig. 4 Comparison of the theoretical results with the results of LVM method

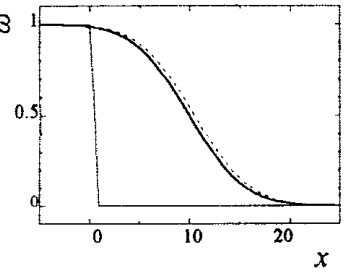

$\mathrm{R}=1$

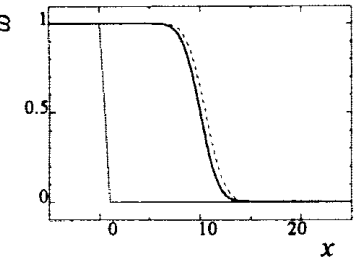

$\mathbf{R}=10$

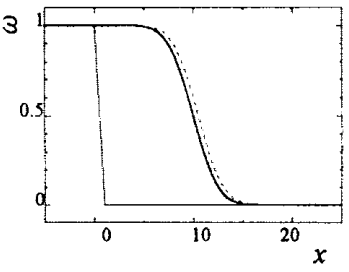

$\mathrm{R}=5$

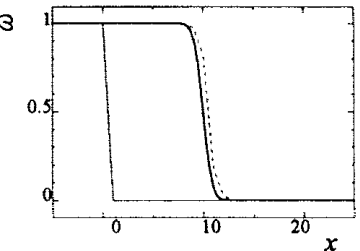

$\mathrm{R}=40$
Fig. 5 Comparison of the theoretical result and the results of LVM method (- Initial value, theoretical result, $\cdots \cdot$ LVM)

$3 \cdot 2$ 計算結果 $3 \cdot 1$ 節に述べた方法により, 一次 元の場合について計算した結果を図 4 および図 5 に示 す.ただし移流速度を $u=1$ ，格子間隔を $\Delta x=1$ とし た.

図 4(a)，(b)は共に格子レイノルズ数 $R(=$ $u \cdot \Delta x / v)$ を 1 に固定し，時間ステッブ $\Delta t$ のみ変化 させた場合を解析したものであり，(a)はステップ状 の初期值 $[(\omega(x)=1(x \leq 0), \omega(x)=0(0<x)]$ が移流拡 
散していく場合, ( b ) は柱状の初期值 $[\omega(x)=1,(-5$ $\leq x<5), \omega(x)=0,(x<-5,5<x)]$ が拡散していく 場合である，時間ステップ $\Delta t$ を大きくしてクーラン 数を 2.0 のように極端に大きくすると解がステップ状 になり誤差が生じているが,一段階の FTCSにおい て安定に計算できる限界に達しているためと考えられ る.しかし図 4(a)，(b)の結果が共に理論解とよく 一致しており、差分法などと違ってクーラン数, 抬散 数を比較的大きくとれることがわかる。

また図 4(a)の場合について, 格子レイノルズ数 $R$ を変化させて解析した結果を図 5 に示す.この結果も 理論解とよく一致している.

よって前報 ${ }^{(2)}$ で提案した渦度の面積配分法を用い た格子渦法に加えて，ここで提案した粘性拡散の手法 を導入することにより，安定性の高い計算が可能とな る。

\section{4. 二次元正方形キャビティ流れ}

4 •1 拡散項の計算 3 章では一次元での格子渦 法の精度を検討したが, 次に二次元の流れにおけるべ ンチマークテストとして, 正方形キャビティ流れの解 析を行う。二次元における㹡散は次のように計算し た。

二次元の場合も $2 \cdot 3$ 節と同様に 2 時間ステップ後の 渦度を与えるものとし，例えば注目した格子の渦度は $(1-4 D+4 D \times D) \omega_{i}^{n}$ となる．隣接の格子も同様な考 え方で渦度分布を与えていく.ただし $3 \cdot 1$ 節で述べた
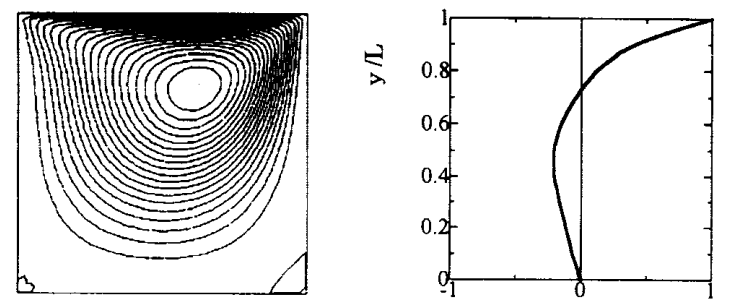

$\mathrm{u} / \mathrm{U}$

(a) $R^{\prime}=100$
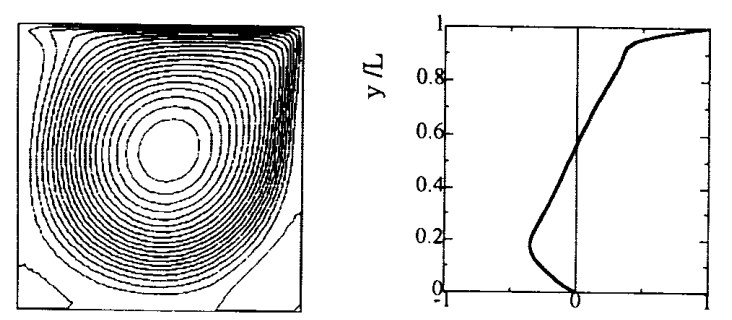

$\mathrm{u} / \mathrm{U}$

(b) $R e=1000$

Fig. 6 Streamlines and Velocity Distribuion by Finite Difference Method
ように，微小時間 $\Delta t$ の間に移流と抎散を同時に行う ため, 移流か拡散のいずれかを $\Delta t / 2$ ずつに分けて 2 ステップの計算を行い，それぞれの時間ステップで.上 記のような考え方で周囲の格子に渦度が配分されるも のとして解析することにした。移流項については前報 で述べた二次精度の計算法に基づいて行った。

$4 \cdot 2$ 解析結果 計算条件については, 格子数は $40 \times 40$ とし, レイノルズ数 $R e=100$, 格子間隔 $\Delta x=$
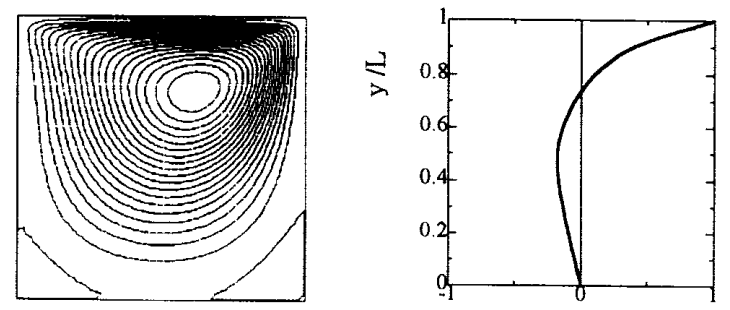

$\mathrm{u} / \mathrm{U}$

(a) $\Delta t=0.2, t=8$, Method-1
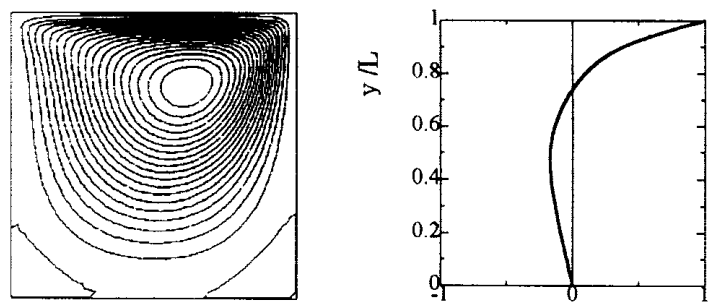

$\mathrm{u} / \mathrm{l}$

(b) $\Delta t=1.0, t=8$, Method-1
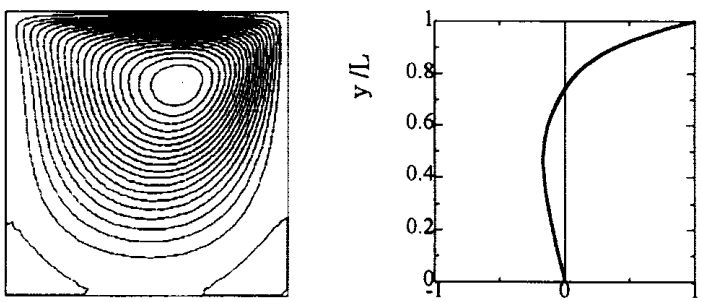

$\mathrm{u} / \mathrm{U}$

(c) $\Delta t=2.0, t=8$, Method-1

Fig. 7 Results of Lattice Vortex Method $(R e=100)$

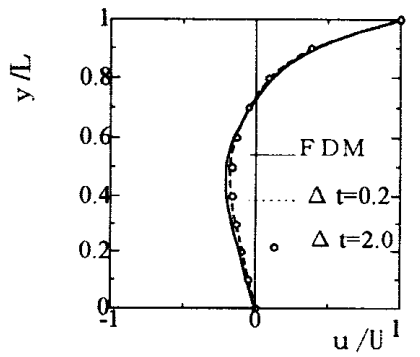

$\operatorname{Re}=100$

Fig. 8 Comparison of Velocity Distribution of FDM with that of LVM 

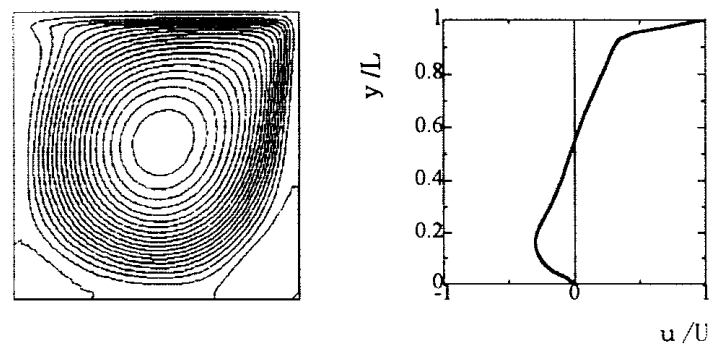

(a) $\Delta t=0.5, t=40$, Method 2
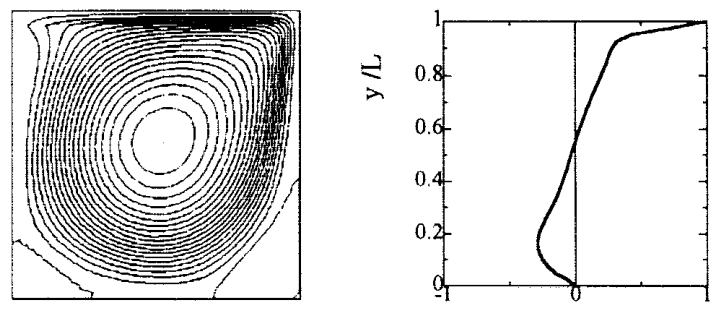

$\mathrm{u} / \mathrm{u}$

(b) $\Delta t=1.0, \quad t=40$, Method 2
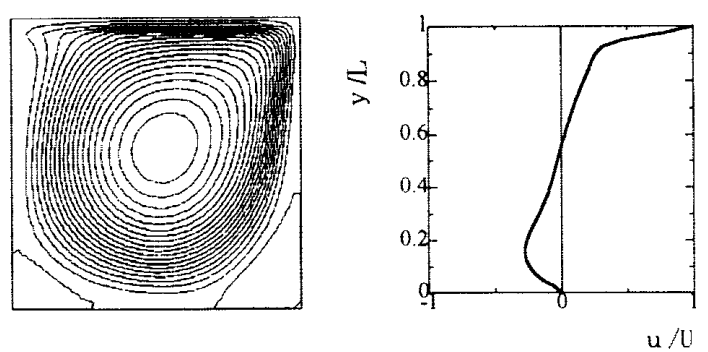

(c) $\Delta t=2.0, t=40$, Method 2

Fig. 9 Streamlines and Velocity Distributions by Lattice Vortex Method $(R e=1000)$

1 とした.

まず比較の対象として, 差分法(定常解, Denis CHang 法)(9)によって二次元キャビティ流れを解析 した結果を図 6 に示寸。格子渦法による解析結果は, $t=8$ での結果を図7に示す。図 6 抢よび図 7 の速度 分布はキャビティ中央の鉛直線上の速度分布を示した ものである。なお，Method-1 は壁面からはみ出した 仮想渦を壁面のすぐ内側の格子に重枋るように処理を 行ったことを示しているが，壁面での仮想渦の処理に ついては次の節で述べる，差分法と格子渦法の結果か ら，流線の様子はよい一致を示している。また鉛直線 上の速度分布を比較したものが図8であり，格子渦法 の結果は差分法の結果とよく一致している.

$4 \cdot 3$ 壁面での仮想渦の処理について 図 6〜8に 示したMethod-10方法では，速度と時間ステップの 関係で流机埸加らはみ出した渦(仮想渦)は，本来流れ 場からは外出すこと结なく，キャビティ内に保存され るはずであると考え，格子のすぐ内側の渦格子にはみ 出した仮想澡を重极ている。しかしながら，格子珮法 では流れ場のすぐ外側に渦格子を一つとり，時間ステ

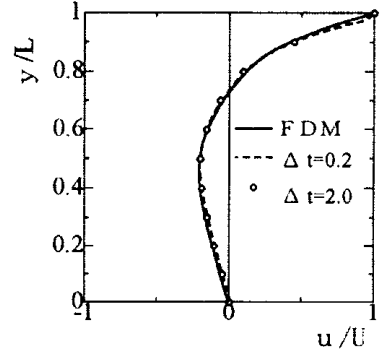

(a) $R e=100$

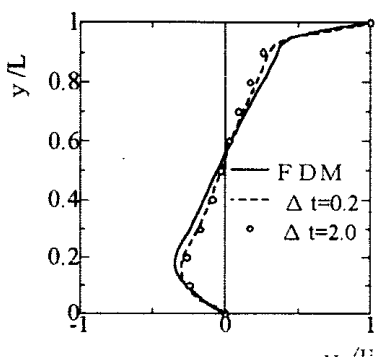

(b) $R e-1000$

Fig. 10 Comparison of the Results of FDM and LVM (Method-2)

ッブを進めるたびに，キャビティのすぐ内側の格子の 渦と外側の格子の渦の大きさを境界条件を満たすよう に計算し直して配置する。そのためキャビティの外に はみ出した伋想渦の影響が無視されることになる。そ こで壁面からはみ出した渦を壁面の寸ぐ内側ではな く，もう一つ内側すなわち壁から 2 番めの渦格子に重 好て渦度を保存させることも検討した。図 9 は $R e=$ 1000 の場合の解析結果であり, Method 2 はこの上 うな方法によって解析したことを示しており，差分法 とほほ一致した流線が得られた。また図 10 に示した 速度分布も比較的よい結果が得られている。

Method-1 と Method-2 については，他の流れに対 して系統的に調べてはいないので，現在これらの優劣 を判断するには至っていない．また， $R e=100$ の流れ においてキャビティ底部の二次渦の流線が，本方法に よる結果と差分法による結果が大きく翼なっているよ うに見えるが，この領域では流れはよどんでおり，流 礼関数の值そのものが小さく，流速が大きな領域に比 較して誤差が大きいわけではない.

\section{5. 結 論}

本研究では，一次元の場合について格子瀜法による 解析精度を検滾した結果，移流項については二次精度 の面積配分法によって消を移流させ，粘性項について は正規分布を近似するように渦度分价を決定すれば良 好な結果が得られることが明らかとなった。また，二 
次元の場合も同様な方法によりキャビティ流れを解析 した結果, 差分法と同等な結果が得られることがわか った。さらに渦格子は渦度の再配分にのみ用い, 渦の 移動はラグランジュ的に行う格子渦法は, 差分法に比 べて拉散数およびクーラン数が大きくとれる長所も有 することがわかった。

\section{文献}

(1) Sarpkaya, T., Trans. ASME, J. Fluids Eng., 111
(1989), 5-52.

(2) Leonard. A., J. Comput. Phys., 37-3 (1980), 289-335.

(3) 蔦原道久 •ほか 3 名, 機講論, No. 96-9 (1996)，219-221.

(4) 点原道久 • ほか 3 名, 機論, 63-614, B(1997)，3209-3215.

（5）大上芳文・赤松映明，機諭，54-505, B(1988)，2283-2290.

（6）新谷吕孝・白不裕之・赤松映明，機論，60-572，B(1994）, 1110-1117.

(7) MacCormack, R. W., AIAA J., 20-9 (1982), 1275-1281.

（8）例元ば，藤井孝蔵，流体力学の数值計算法，(1994)，141 142 , 東京大学出版会.

（9）日本機械学会編, 数值シミュレーション, (1988)，89-93, コロナ社. 